\title{
Photochemical Response in 0-Year-Old and 1-Year-Old Needles of Picea glehnii during Cold Acclimation and Low Temperature
}

\author{
Bae, Jeong-Jin ${ }^{1,2}$, Toshihiko Hara ${ }^{1}$ and Yeon-Sik Choo ${ }^{2 *}$ \\ ${ }^{1}$ Cryosphere Science Research Section, Institute of Low TemperatureScience, Hokkaido Univ., Sapporo 060-0819, Japan \\ ${ }^{2}$ Plant Ecophysiology Lab., Department of Biology, Kyungpook National Univ., Daegu 702-701, Korea
}

\begin{abstract}
P. glehnii, an evergreen conifer found in northern areas, is known as a cold-resistant species. In this experiment, we measured the water content, PS II efficiency, chlorophyll fluorescence, pigments of the xanthophyll-cycle and activity of enzymes of the ascorbate-glutathione cycle during cold acclimation and at subsequent low-temperature conditions to examine the importance of acclimation to cold tolerance. $P$. glehnii showed a decrease in PS II efficiency (especially in Fv) during cold acclimation and at subsequent low temperatures. However, cold-acclimated needles showed higher PS II efficiency at low temperatures than nonacclimated needles. In addition, 0-YON (first-year needles) showed an increase in $\beta$-carotene and lutein, while 1-YON (one-year-old needles) immediately developed an antioxidant mechanism in the ascorbate-gluthathione cycle as soon as they were exposed to low temperature and both 0-YON and 1-YON showed increased zeaxanthin and de-epoxidation ratios at continuous low temperature. Based on our results, we suggest that $P$. glehnii maintain PS II efficiency at low temperature by effectively protecting the photosynthetic apparatus from photo-damage by rapid induction of an antioxidant mechanism in 1-YON and dissipation of excess energy by $\beta$-carotene and lutein in $0-Y O N$.
\end{abstract}

Key words: Ascorbate-glutathione cycle, Cold acclimation, Cold resistance, P. glehnii, PS II efficiency, Xanthophyll-cycle.

\section{INTRODUCTION}

P. glehnii is an evergreen conifer distributed in southern Siberia and northern Japan. This plant is commonly called Sakhalin spruce and is known as a cold-resistant species that can survive at extreme low temperatures during winter. Cold acclimation is a very important factor facilitating survival of plants at low temperatures especially in the northern zone. In the temperate zone, a gradual decline in temperatures in late autumn acts as a cue of the coming winter, causing woody plants to initiate various cold resistance mechanisms, such as increased levels of ABA (Veisz et al. 1996), changes in fatty acids (Murelli et al. 1995), and growth restriction (KacperskaDalacz 1978). Cold-acclimated Arabidopsis, spinach, and cabbage survived even at freezing temperatures despite being herbaceous plants, and winter cereals showed higher resistance to photoinhibition at low temperature after acclimation at $5{ }^{\circ} \mathrm{C}$ (Öquist and Huner 1991, Strand et al. 1999).

Worldwide, the average air temperature is gradually increasing due to human activities and elevated temperatures are disturbing the process of cold acclimation in perennial plants (Heide 1993). Therefore, many plants are put at risk of temperature shock by sudden exposure to slow temperatures without proper cold acclimation. This phenomenon can cause more severe damage in high-latitude plants than low-latitude plants. Plants may suffer serious consequences from cold damage even at above-zero temperatures in early spring when the cold-acclimation process was not properly completed, and this damage has negative effects on the productivity of woody plants (Pearce 1999). The purpose of our study was to determine the mechanisms related to cold resistance in the photosynthetic apparatus of first-year needles (0-YON) and one-year-old needles (1-YON) and to determine whether the protective mechanisms are induced directly by the cold-acclimation process. We investigated the capacity for $\mathrm{CO}_{2}$ fixation, relative water content, PSII efficiency, chlorophyll fluorescence, xanthophyll-cycle pigments, and activity of enzymes related to the ascorbate-gluthathione cycle of $P$. glehnii, a cold-resistant species during cold acclimation, at subsequent low temperatures, and during a recovery period.

\section{MATERIALS AND METHODS}

\section{Experimental Design}

We divided a sample of $30 \sim 35 \mathrm{~cm}$ saplings into two sets. One set, the non-acclimated group, was grown in a growth chamber at

\footnotetext{
* Corresponding author; Phone: +82-53-950-5346, e-mail: yschoo@knu.ac.kr
} 
$25 / 20^{\circ} \mathrm{C}$ (day/night), the other set, the cold-acclimated group, was kept at $15 / 10^{\circ} \mathrm{C}$ for 10 days and then at $5 / 0{ }^{\circ} \mathrm{C}$ for 10 days. A photoperiod of $12 \mathrm{~h}$ was used for all acclimation stages. We used low irradiance (100 $\mu \mathrm{mol} \mathrm{m}{ }^{-2} \mathrm{~s}^{-1}$ ) to prevent serious photoinhibition by low temperatures. Non-acclimated and cold-acclimated plants were then randomly divided into two groups: a control group and a treatment (chilling) group. Saplings were placed at $0 / 0^{\circ} \mathrm{C}$ (for the chilling group) or $25 / 20^{\circ} \mathrm{C}$ (for the control group) under the same conditions. After temperature treatment, all plants were allowed to undergo a two-week recovery process.

\section{Determination of Water Content}

The relative water content (RWC) was calculated according to the following equation: RWC $(\%)=(F W-D W) /(T W-D W) \times 100$, where $\mathrm{FW}=$ fresh weight, DW = dry weight, and TW = turgid weight. The dry weight of the samples was measured after drying for 72 $\mathrm{h}$ in an oven at $80^{\circ} \mathrm{C}$ and turgid weight was measured after holding samples for $12 \mathrm{~h}$ in distilled water at $4^{\circ} \mathrm{C}$ (Cameron et al. 1999).

\section{Extraction and Analysis of Pigments}

Total chlorophyll and carotenoids in $P$. glehnii needles was measured using the method of Gilmore and Yamamoto (1991) with slight modifications. Frozen needles (about $50 \mathrm{mg}$ ) were homogenized with liquid nitrogen and extracted with $100 \%$ (v/v) acetone. The extract was centrifuged at $4{ }^{\circ} \mathrm{C}$ for $3 \mathrm{~min}$ at $14,400 \mathrm{rpm}$, and the supernatant was analyzed for plant pigments using high-perfor- mance liquid chromatography (HPLC; ; LC-Vp series, Shim-pack CLC column (150 mm long, $6 \mathrm{~mm}$ ), Shimadzu, Kyoto, Japan).

\section{Chlorophyll Fluorescence Parameters}

We measured chlorophyll fluorescence parameters of needles with a pulse amplitude-modulated fluorometer (PAM 2000, Heinz Walz, Effeltrich, Germany) after dark-adaptation for $15 \mathrm{~min}$ at $22^{\circ} \mathrm{C}$. Variable fluorescence (Fv) was calculated by subtracting Fo from Fm. We also measured photochemical (qP) and non-photochemical quenching (qN) parameters of chlorophyll fluorescence.

\section{Photosynthetic Rate}

We measured $\mathrm{CO}_{2}$ exchange with a portable gas exchange system (LI-6400: LI-Cor, Licoln, NE. USA). The leaf was irradiated at moderate PPFD of $100 \mu \mathrm{mol} \mathrm{m}^{-2} \mathrm{~s}^{-1}$ at the leaf temperature of $25^{\circ} \mathrm{C}$.

\section{Extraction and Assay of Ascorbate-Glutathione Cycle Enzymes}

Frozen needle samples (about $50 \mathrm{mg}$ ) were ground with liquid nitrogen and homogenized with $500 \mu \mathrm{L}$ of $50 \mathrm{mM}$ potassium phosphate buffer ( $\mathrm{pH} 7.8$, containing $0.01 \mathrm{~g}$ myo-inositol and PVP, $40 \mu \mathrm{L}$ of $0.1 \mathrm{mM}$ AsA and $20 \mu \mathrm{L}$ of $0.1 \mathrm{mM}$ 2Na-EDTA). The homogenate was centrifuged at $15,000 \mathrm{rpm}$ for $10 \mathrm{~min}$ at $4{ }^{\circ} \mathrm{C}$, and supernatant was assayed for sAPX and GR. For tAPX, we added $40 \mu \mathrm{L}$ of $0.1 \mathrm{mM} \mathrm{AsA}, 500 \mu \mathrm{L}$ of $50 \mathrm{mM}$ potassium phosphate buffer (pH 7.8 containing $0.5 \%(\mathrm{v} / \mathrm{v})$ Triton $\mathrm{X}-100)$ into the re-

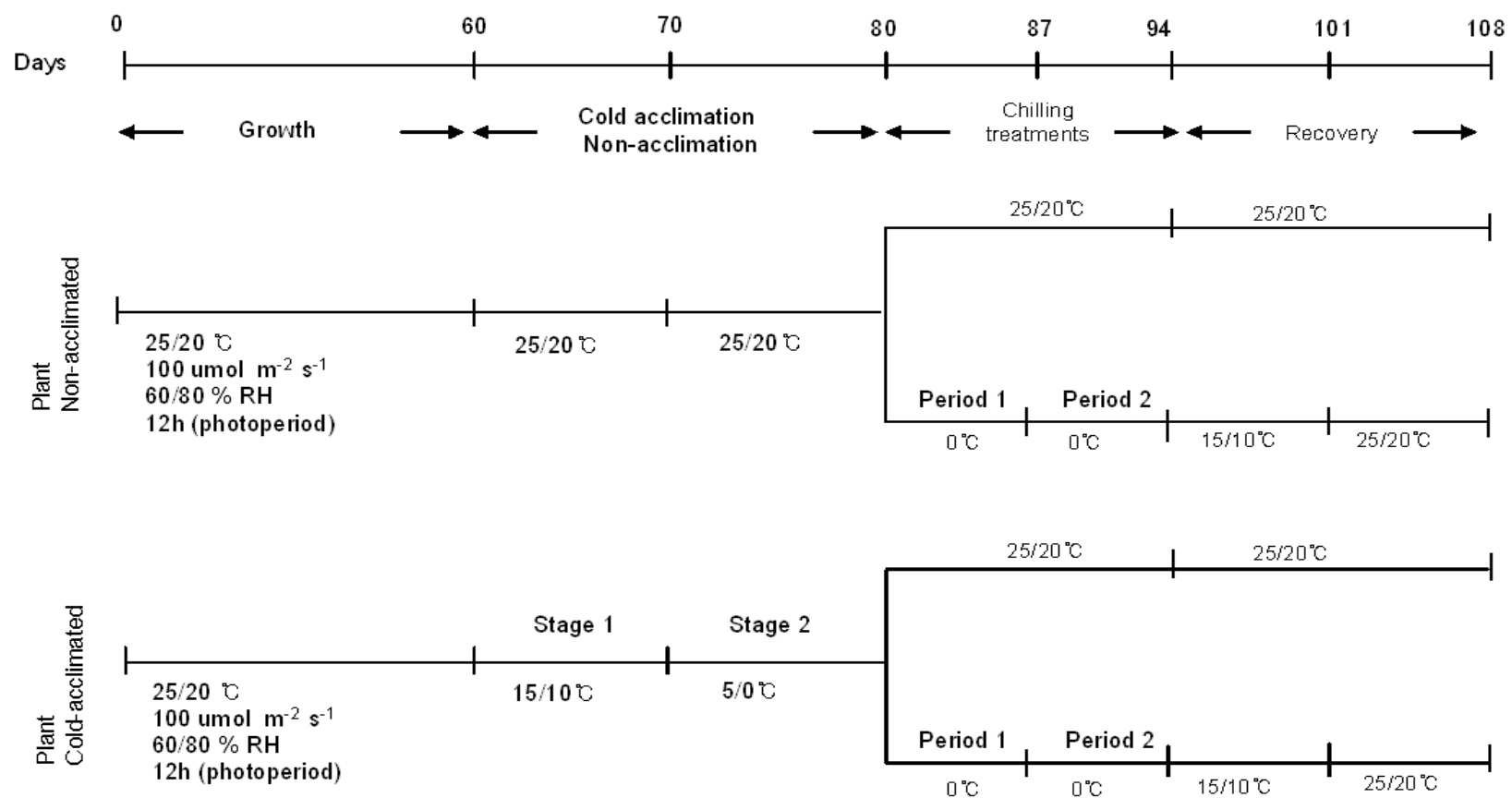

Fig. 1. Experimental design. 
maining sediment within the tube after extraction of sAPX, centrifuged the mixture with the same conditions, and used the supernatant (the enzyme extract) for activity measurement. To measure the activity of sAPX and tAPX, the reaction mixture ( $5 \mu \mathrm{L}$ of 0.1 $\mathrm{mM}$ AsA, $985 \mu \mathrm{L}$ of $50 \mathrm{mM}$ potassium phosphate buffer ( $\mathrm{pH} 7.0$ ) was mixed with $10 \mu \mathrm{L}$ of plant extracts to a total volume of 1 $\mathrm{mL}$. The reaction was started by adding $0.1 \mathrm{mM}$ hydrogen peroxide $\left(\mathrm{H}_{2} \mathrm{O}_{2}\right)$. For $\mathrm{GR}$, the same reaction mixture was mixed with $10 \mu \mathrm{L}$ of $0.1 \mathrm{mM}$ 2Na-EDTA (pH 8.0), $10 \mu \mathrm{L}$ of $100 \mathrm{mM}$ GSSG (oxidized glutathione), $10 \mu \mathrm{L}$ of $10 \mathrm{mM} \mathrm{NADPH}, 40 \mu \mathrm{L}$ of distilled water and $30 \mu \mathrm{L}$ of plant extracts. Enzyme extractions were prepared at $4{ }^{\circ} \mathrm{C}$, and assays were determined at $25^{\circ} \mathrm{C}$. The APX and GR activity were determined with a UV-visible spectrophotometer (Bemkman DU 7400, U.S.A.) using the molecular extinction coefficients of $2.8 \mathrm{mM}^{-1} \mathrm{~cm}^{-1}$ for AsA at $290 \mathrm{~nm}$ and $6.2 \mathrm{mM}^{-1}$ $\mathrm{cm}^{-1}$ for $\mathrm{GR}$ at $340 \mathrm{~nm}$.

\section{Statistical Analysis}

The results presented are means \pm SE of three independent replicates. Data for cold-acclimated and non-acclimated needles were calculated using ANOVA (completely randomized). The multiple range test after Bonferroni-corrected comparisons was carried out to test for the significance differences $(p<0.05)$ between cold-acclimated or non-acclimated needles (using SPSS 12.0 for Windows).

\section{RESULTS}

\section{Relative Water Content}

The cold-acclimation process resulted in a slight decrease in RWC in both 0-YONs and 1-YONs (95 and 97\%, respectively, on the $20^{\text {th }}$ day of cold acclimation). 0 -YONs usually had a higher RWC than 1-YONs. However, the RWC recovered to the initial values when the needles were returned to normal (warm) conditions after cold acclimation (Fig. 2A, B). In the chilling condition $\left(0^{\circ} \mathrm{C}\right)$ after cold acclimation, cold-acclimated 0 -YONs and 1-YONs did not show decreases in RWC on the $14^{\text {th }}$ day after chilling $(97 \%$ and $104 \%$, respectively) but non-acclimated needles exhibited decreases in RWC and the decrease was more remarkable in 0-YONs than 1 -YONs (90\% and 96\%, respectively) (Fig. 2C, D). However, the leaves did not display visible symptoms of tissue damage such as necrosis at low temperature.

\section{$\mathrm{CO}_{2}$ Fixation}

During cold acclimation, the efficiency of $\mathrm{CO}_{2}$ fixation decreased sharply by $>30 \%$ (relative to control plants) as soon as plants were exposed to low temperature (cold acclimation stage1: $15 / 10^{\circ} \mathrm{C}$ ). However, the photosynthetic activity of $P$. glehnii needles that had been acclimated to cold progressively during a gradual decline in temperatures recovered to $70 \%$ of the control level at subsequent stages of cold acclimation, even at lower temperatures (stage $2 ; 5 / 0^{\circ} \mathrm{C}$ ) (Fig. 3).

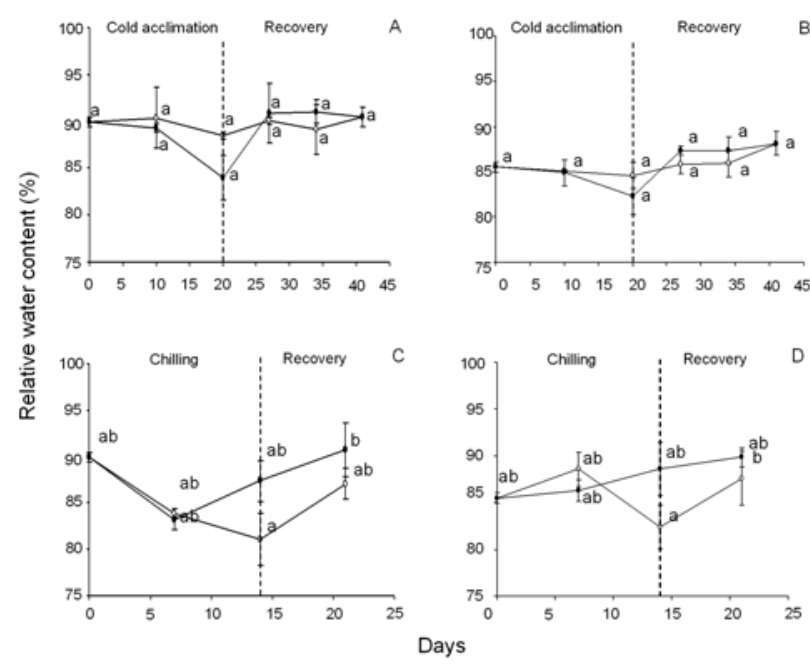

Fig. 2. Changes in relative water content (RWC) during cold acclimation and recovery in 0-year-old needles (A) and 1-year-old needles (B) and during chilling treatment and recovery in 0-year-old needles (C) and 1-year-old needles (D) in $P$. glehnii. Closed and open symbols represent cold-acclimated and non-acclimated needles. Values are means \pm SE $(n=3)$. The same letters indicate non-significant differences in Bonferroni multiple comparisons $(p<0.05)$.

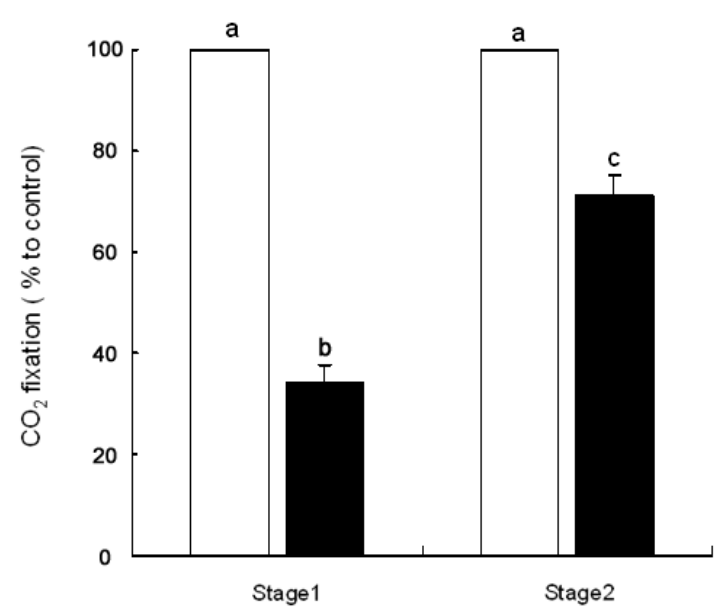

Fig. 3. The relative photosynthetic activity during cold acclimation (stage $1: 15 / 10^{\circ} \mathrm{C}$ for 10 days, stage $2: 5 / 0^{\circ} \mathrm{C}$ for 10 days after stage 1) in $P$. glehnii. Closed and open symbols represent cold-acclimated and non-acclimated (control) needles. Values are means $\pm \operatorname{SE}(n=3)$. The same letters indicate non-significant differences in Bonferroni multiple comparisons $(p<0.05)$. 


\section{PSII Efficiency}

The initial Fv/Fm was approximately 0.8, but the PSII efficiency decreased as soon as the plants were exposed to low temperature (especially in 0-YONs). However, all 0-YONs and 1-YONs recovered PSII efficiency rapidly and reached the initial values of $\mathrm{Fv} / \mathrm{Fm}$ when they were returned to normal conditions $\left(25 / 20^{\circ} \mathrm{C}\right)$ after cold acclimation (Fig. 4A, B). While cold-acclimated needles exhibited a decrease in Fv/Fm during subsequent chilling, they showed higher PSII efficiency than non-acclimated needles at low temperatures and during the recovery period (Fig. 4C, D). Therefore, we conclude that cold-acclimated needles undergo less photoinhibition at low temperatures than non-acclimated ones, and that cold acclimation increases the ability of the PSII to resist photoinhibition in P. glehnii.

\section{Chlorophyll Fluorescence}

Cold-acclimation of P. glehnii led to an increase in Fo (Fig. 5A, B) and a decrease in Fv and Fm (Figs. 6A, B, 7A, B). These changes were more distinct in 0 -YONs than 1-YONs, particularly the reduction in the $\mathrm{Fv}$ component (Fig. 6A, B). Fv values of 1 -YONs were more stable than those of 0 -YONs during cold acclimation, and showed similar patterns such as the drop in Fv during subsequent chilling. (Fig. 6C, D; $14^{\text {th }}$ day after chilling treatment). From these results, we suggest that cold tolerance and resistance to cold damage in $P$. glehnii are closely concerned with Fv (the fraction related with reaction centre of PSII).

\section{Photochemical and Non-photochemical Quenching}

Under low temperature conditions, 1-YONs actively got rid of

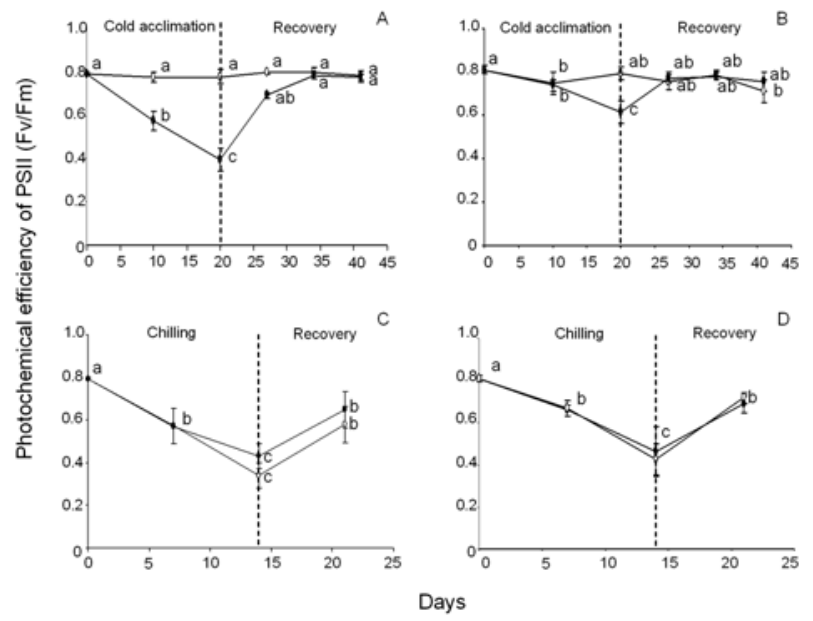

Fig. 4. Changes in maximal photochemical efficiency of PSII (Fv/ Fm) during cold acclimation and recovery in 0-year-old needles (A) and 1-year-old needles (B) and during chilling treatment and recovery in 0-year-old needles (C) and 1-year-old needles (D) in P. glehnii. Symbols as in Fig. 2. $n=6$. excess energy through both of photochemical and non-photochemical quenching, while 0 -YONs did so only through non-photochemical quenching because of severe inhibition of photochemical quenching at low temperature (Figs. 8, 9). Meanwhile, cold-acclimated 0-YONs and 1-YONs maintained higher levels of non-photochemical quenching during the recovery period after exposure to low temperatures (Figs. 9C, D). These results suggest that the process of cold acclimation in P. glehnii induces the development of non-photochemical quenching mechanisms related to the recovery capacity and tolerance to cold stress.

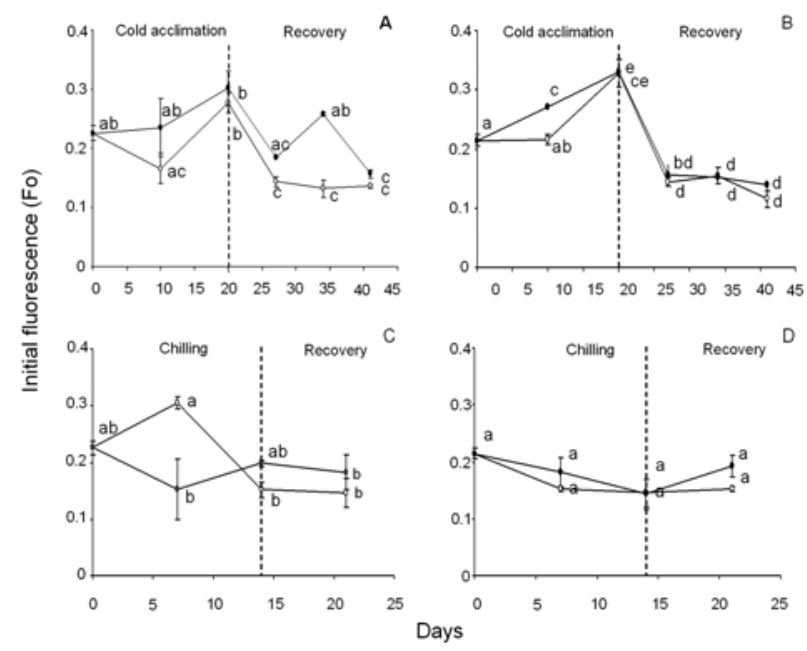

Fig. 5. Changes in Fo during cold acclimation and recovery in 0-yearold needles (A) and 1-year-old needles (B) and during chilling treatment and recovery in 0-year-old needles (C) and 1-yearold needles (D) in P. glehnii. Symbols as in Fig. 2. $n=6$.

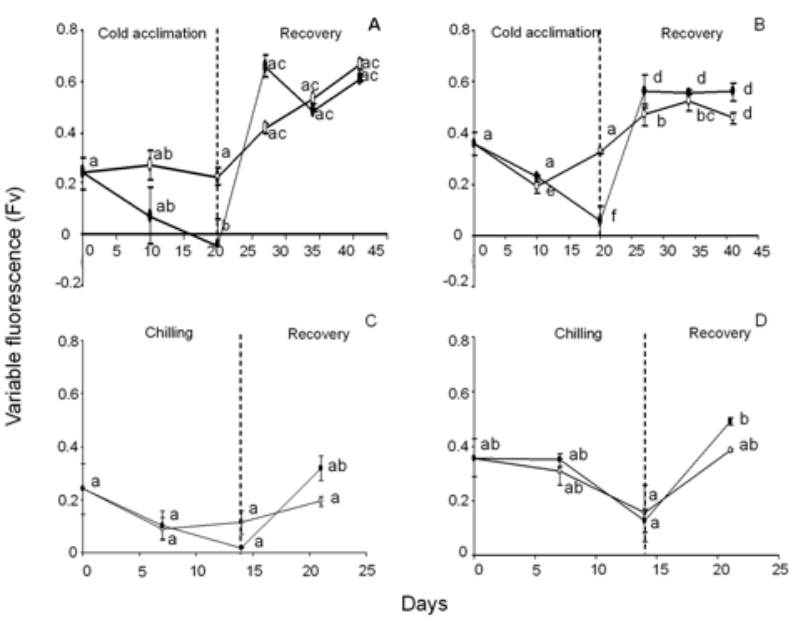

Fig. 6. Changes in Fv during cold acclimation and recovery in 0-yearold needles (A) and 1-year-old needles (B) and during chilling treatment and recovery in 0-year-old needles (C) and 1-yearold needles (D) in P. glehnii. Symbols as in Fig. 2. $n=6$. 


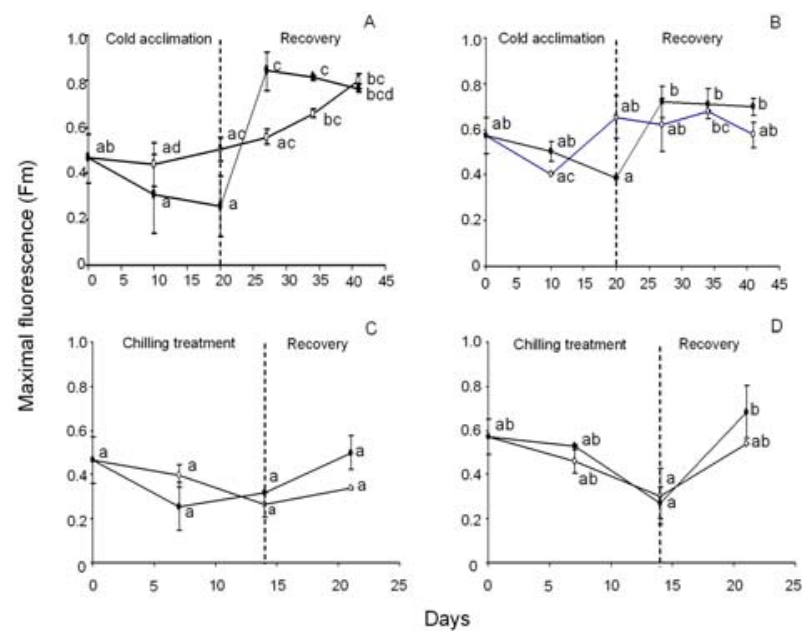

Fig. 7. Changes in Fm during cold acclimation and recovery in 0-yearold needles (A) and 1-year-old needles (B) and during chilling treatment and recovery in 0-year-old needles $(\mathrm{C})$ and 1-yearold needles (D) in P. glehnii. Symbols as in Fig. 2. $n=6$.

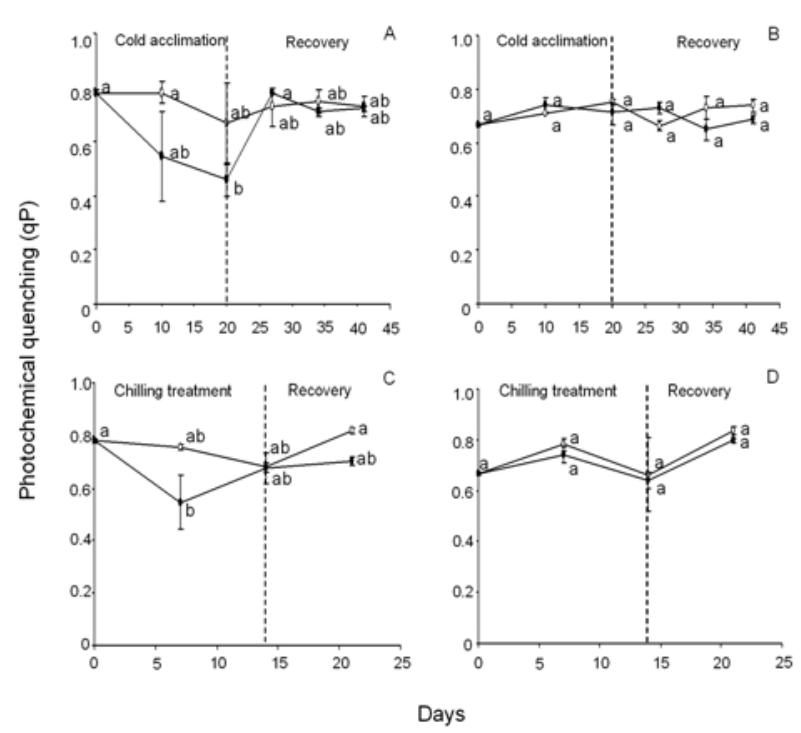

Fig. 8. Changes in photochemical quenching $(\mathrm{qP})$ during cold acclimation and recovery in 0-year-old needles (A) and 1-year-old needles (B) and during chilling treatment and recovery in 0 -year-old needles (C) and 1-year-old needles (D) in P. glehnii. Symbols as in Fig. 2. $n=6$.

\section{Xanthophyll-Cycle Pigments and De-Epoxidation Ratio}

The de-epoxidation ratio of violaxanthin to zeaxanthin increased by $209 \sim 458 \%$ in cold-acclimated 0 -YONs and 1-YONs compared to non-acclimated needles in stage 2 of cold acclimation (on the $14^{\text {th }}$ day after cold acclimation). Cold-acclimated needles also maintained higher levels of zeaxanthin and de-epoxidation ratios in the subsequent chilling period (Table 1).

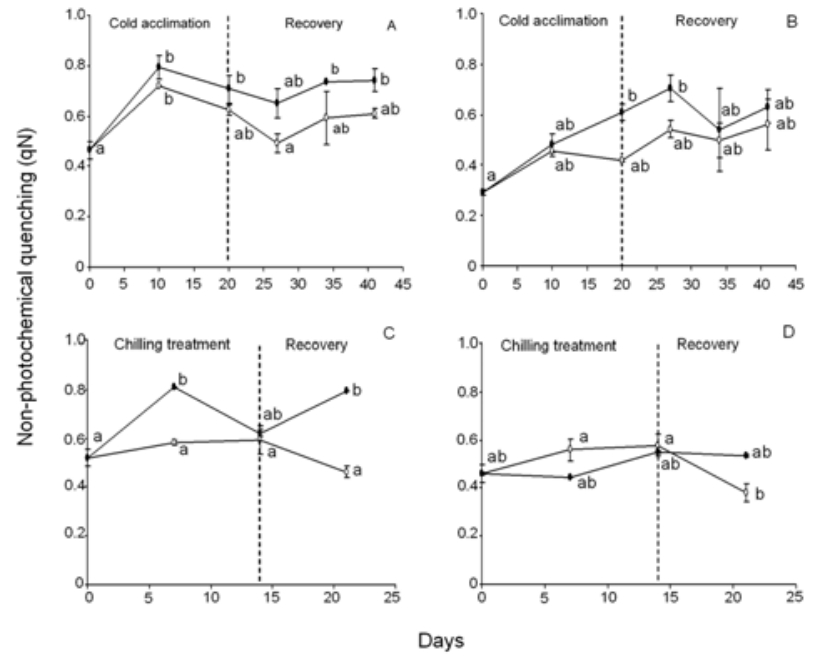

Fig. 9. Changes in non-photochemical quenching (qN) during cold acclimation and recovery in 0-year-old needles (A) and 1-year-old needles (B) and during chilling treatment and recovery in 0-year- old needles (C) and 1-year-old needles (D) in P. glehnii. Symbols as in Fig. 2. $n=6$.

\section{Lutein and $\beta$-Carotene Contents}

Low temperatures immediately induced an increase in lutein and $\beta$-carotene, especially in 0 -YONs, and cold-acclimated 0 -YONs maintained increased lutein and $\beta$-carotene contents during subsequent chilling (Table 1).

\section{Ascorbate-Glutathione Cycle Enzymes}

Enzyme activity of 1-YONs increased as soon as they were exposed to low temperature (stage 1 of cold acclimation) (Table 2B). On the other hand, activity levels in 0-YONs decreased at first (in stage 1 of cold acclimation) but then increased at continuous low temperature (in stage 2 of cold acclimation) (Table 2A). These results suggest that the antioxidation mechanism involving the ascorbate-glutathione cycle in 1-YONs of $P$. glehnii provides effective protection by acting quickly at low temperature. Although 0 YONs did not show an immediate increase in enzyme activity at low temperature during cold acclimation, they displayed enhanced enzyme activity at continuous low temperature until stage 1 of chilling. In contrast, 1-YONs at low temperature showed a more rapid increase of activities. However, enzyme activity was lower in coldacclimated needles than non-acclimated needles at subsequent low temperatures and remained low until stage 2 of chilling (Table 2B).

\section{DISCUSSION}

\section{Relative Water Content and $\mathrm{CO}_{2}$ Fixation}

P. glehnii needles showed a decrease in RWC (Fig. 2) and $\mathrm{CO}_{2}$ 
Table 1. Contents of carotenoids (mmol mol $\mathrm{Chl}^{-1}$ ) and de-epoxidation ratio $(\mathrm{A}+\mathrm{Z}) /(\mathrm{V}+\mathrm{A}+\mathrm{Z}$ ) during cold acclimation and the chilling period for 0-YON (0-year-old needles) and 1-YON (1-year-old ones) in P. glehnii. (NA: non-acclimated, CA: cold-acclimated). Values are means \pm SE $(n=3)$. The same letters indicate non-significant differences in Bonferroni multiple comparisons $(p<0.05)$.

\begin{tabular}{|c|c|c|c|c|c|c|c|c|}
\hline & \multicolumn{8}{|c|}{ Cold acclimation } \\
\hline & \multicolumn{4}{|c|}{ Stage $1\left(15 / 10^{\circ} \mathrm{C}\right)$} & \multicolumn{4}{|c|}{ Stage $2\left(5 / 0^{\circ} \mathrm{C}\right)$} \\
\hline & 0-YON (NA) & 0-YON (CA) & 1-YON (NA) & 1-YON (CA) & 0-YON (NA) & 0 -YON (CA) & 1-YON (NA) & 1-YON (CA) \\
\hline Zeaxanthin & $0.62 \pm 0.03 a$ & $0.161 \pm 0.228 \mathrm{a}$ & $20.099 \pm 2.733 b$ & $6.971 \pm 0.04 a$ & $5.529 \pm 4.474 a$ & $62.642 \pm 5.219 c$ & $1.155 \pm 0.001 \mathrm{a}$ & $38.034 \pm 0.213 d$ \\
\hline Violaxanthin & $9.202 \pm 1.616 \mathrm{ac}$ & $10.452 \pm 2.154 \mathrm{a}$ & $7.604 \pm 1.091 \mathrm{abc}$ & $8.931 \pm 0.218 \mathrm{ac}$ & $10.363 \pm 2.083 a$ & $2.987 \pm 0.027 b$ & $12.460 \pm 0.551 \mathrm{a}$ & $4.204 \pm 0.206 \mathrm{bc}$ \\
\hline Deepoxidation & $0.318 \pm 0.041 \mathrm{ac}$ & $0.191 \pm 0.026 a$ & $0.780 \pm 0.001 \mathrm{bd}$ & $0.545 \pm 0.016 \mathrm{c}$ & $0.459 \pm 0.161 \mathrm{ac}$ & $0.958 \pm 0.003 \mathrm{bd}$ & $0.199 \pm 0.002 \mathrm{a}$ & $0.911 \pm 0.003 \mathrm{bd}$ \\
\hline Lutein & $44.622 \pm 1.215 \mathrm{ab}$ & $54.96 \pm 5.318 \mathrm{bc}$ & $63.503 \pm 9.361 \mathrm{bc}$ & $53.506 \pm 1.631 b c$ & $57.277 \pm 6.634 \mathrm{bc}$ & $71.476 \pm 4.33 c$ & $58.98 \pm 0.625 b c$ & $57.56 \pm 0.187 \mathrm{bc}$ \\
\hline \multirow[t]{4}{*}{$\beta$-Carotene } & $18.942 \pm 2.96 a$ & $24.516 \pm 2.938 \mathrm{a}$ & $26.577 \pm 2.729 a$ & $17.597 \pm 2.543 \mathrm{a}$ & $20.773 \pm 2.25 a$ & $26.852 \pm 3.214 \mathrm{a}$ & $23.806 \pm 1.025 \mathrm{a}$ & $22.486 \pm 0.769 \mathrm{a}$ \\
\hline & \multicolumn{8}{|c|}{ Chilling treatment after cold acclimation } \\
\hline & \multicolumn{4}{|c|}{ Period 1 (on $7^{\text {th }}$ day after chilling treatment) } & \multicolumn{4}{|c|}{ Period 2 (on $14^{\text {th }}$ day after chilling treatment) } \\
\hline & 0 -YON (NA) & 0-YON (CA) & 1-YON (NA) & 1-YON (CA) & 0-YON (NA) & 0 -YON (CA) & 1-YON (NA) & 1-YON (CA) \\
\hline Zeaxanthin & $34.136 \pm 4.902 \mathrm{ac}$ & $43.082 \pm 2.905 \mathrm{a}$ & $25.368 \pm 0.031 \mathrm{c}$ & $43.291 \pm 0.056 \mathrm{a}$ & $46.409 \pm 3.576 \mathrm{a}$ & $61.681 \pm 4.963 b$ & $32.131 \pm 0.943 \mathrm{ac}$ & $44.175 \pm 1.468 \mathrm{a}$ \\
\hline Violaxanthin & $2.712 \pm 0.386 \mathrm{ac}$ & $3.224 \pm 0.386 \mathrm{ac}$ & $6.162 \pm 0.096 b$ & $4.038 \pm 0.006 \mathrm{c}$ & $2.477 \pm 0.195 a$ & $1.429 \pm 0.144 \mathrm{~d}$ & $5.721 \pm 0.106 b$ & $4.328 \pm 0.122 \mathrm{c}$ \\
\hline Deepoxidation & $0.931 \mathrm{a}$ & $0.940 \mathrm{~b}$ & $0.841 \pm 0.003 c$ & $0.927 \mathrm{a}$ & $0.952 \mathrm{~d}$ & $0.978 \mathrm{e}$ & $0.874 \pm 0.001 \mathrm{f}$ & $0.926 \mathrm{a}$ \\
\hline Lutein & $49.895 \pm 4.929 \mathrm{~b}$ & $65.36 \pm 2.26 \mathrm{ac}$ & $66.33 \pm 0.274 a$ & $66.455 \pm 0.668 \mathrm{a}$ & $53.925 \pm 2.649 b c$ & $67.599 \pm 3.992 \mathrm{a}$ & $62.637 \pm 0.639 \mathrm{ac}$ & $67.724 \pm 1.009 \mathrm{a}$ \\
\hline$\beta$-Carotene & $24.504 \pm 1.999 \mathrm{ac}$ & $25.422 \pm 0.635 \mathrm{ac}$ & $25.55 \pm 0.107 \mathrm{ac}$ & $25.917 \pm 0.321 \mathrm{ac}$ & $18.976 \pm 0.213 \mathrm{~b}$ & $23.031 \pm 0.199 \mathrm{a}$ & $24.052 \pm 0.192 \mathrm{ac}$ & $26.898 \pm 0.785 c$ \\
\hline
\end{tabular}

Table 2. Changes in activities of enzyme of ascorbate-glutathione cycle (sAPX, tAPX, GR) during cold acclimation and the chilling period for 0-year-old needles (A) and 1-year-old ones (B) in P. glehnii. (NA: non-acclimated, CA: cold-acclimated). Values of mean \pm SE ( $n=3$ ). The same letters indicate non-significant differences in Bonferroni multiple comparisons $(p<0.05)$.

\begin{tabular}{|c|c|c|c|c|c|c|c|c|}
\hline \multirow{3}{*}{0 -year-old needles } & \multicolumn{4}{|c|}{ Cold acclimation } & \multicolumn{4}{|c|}{ Chilling treatment after cold acclimation } \\
\hline & \multicolumn{2}{|c|}{ Stage 1} & \multicolumn{2}{|c|}{ Stage 2} & \multicolumn{2}{|c|}{ Period 1} & \multicolumn{2}{|c|}{ Period 2} \\
\hline & NA & $\mathrm{CA}$ & NA & CA & NA & CA & NA & $\mathrm{CA}$ \\
\hline 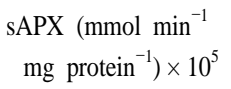 & $6.173 \pm 0.484 a$ & $4.831 \pm 1.96 \mathrm{a}$ & $2.523 \pm 0.282 \mathrm{a}$ & $4.571 \pm 0.749 \mathrm{a}$ & $2.916 \pm 1.097 \mathrm{a}$ & $3.111 \pm 0.816 \mathrm{a}$ & $2.446 \pm 1.391 \mathrm{a}$ & $2.805 \pm 0.025 \mathrm{a}$ \\
\hline $\begin{array}{l}\text { tAPX }(\mathrm{mmol} \mathrm{min} \\
\left.\mathrm{mg} \mathrm{Chl}^{-1}\right) \times 10^{3}\end{array}$ & $9.625 \pm 3.045 a$ & $6.124 \pm 1.915 \mathrm{a}$ & $11.277 \pm 2.046 \mathrm{ab}$ & $20.623 \pm 0.264 b$ & $5.995 \pm 1.751 \mathrm{a}$ & $5.607 \pm 1.321 \mathrm{a}$ & $10.463 \pm 1.389 a b$ & $6.218 \pm 2.433 \mathrm{a}$ \\
\hline \multirow[t]{2}{*}{$\begin{array}{l}\text { GR }(\mathrm{mmol} \mathrm{min} \\
\left.\text { protein }^{-1}\right) \times 10^{5}\end{array}$} & $3.235 \pm 0.317 \mathrm{a}$ & $1.236 \pm 0.335 \mathrm{a}$ & $2.807 \pm 0.493$ & $1.46 \pm 0.474 a$ & $1.044 \pm 0.060 \mathrm{a}$ & $1.638 \pm 0.642 \mathrm{a}$ & $0.717 \pm 0.440 \mathrm{a}$ & $0.308 \pm 0.013 a$ \\
\hline & \multicolumn{4}{|c|}{ Cold acclimation } & \multicolumn{4}{|c|}{ Chilling treatment after cold acclimation } \\
\hline \multirow[t]{2}{*}{ 1-year-old needles } & \multicolumn{2}{|c|}{ Stage 1} & \multicolumn{2}{|c|}{ Stage 2} & \multicolumn{2}{|c|}{ Period 1} & \multicolumn{2}{|c|}{ Period 2} \\
\hline & NA & CA & NA & CA & NA & CA & NA & $\mathrm{CA}$ \\
\hline $\begin{array}{l}\operatorname{sAPX}\left(\mathrm{mmol} \mathrm{min}^{-1}\right. \\
\left.\text { mg protein }^{-1}\right) \times 10^{5}\end{array}$ & $3.426 \pm 0.515 \mathrm{a}$ & $6.509 \pm 1.486 b$ & $5.848 \pm 1.334 \mathrm{ab}$ & $5.149 \pm 0.808 \mathrm{ab}$ & $8.802 \pm 0.039 b$ & $5.801 \pm 0.229 \mathrm{ab}$ & $4.567 \pm 1.272$ a & $4.761 \pm 0.662 \mathrm{a}$ \\
\hline $\begin{array}{l}\text { tAPX }(\mathrm{mmol} \mathrm{min} \\
\left.\text { mg } \mathrm{Chl}^{-1}\right) \times 10^{3}\end{array}$ & $18.699 \pm 0.50 \mathrm{a}$ & $19.634 \pm 2.08 \mathrm{a}$ & $12.578 \pm 7.12 \mathrm{ab}$ & $16.551 \pm 4.69 \mathrm{ab}$ & $5.972 \pm 0.629 \mathrm{ab}$ & $5.923 \pm 0.019 \mathrm{ab}$ & $8.153 \pm 1.026 \mathrm{ab}$ & $1.854 \pm 0.620 \mathrm{~b}$ \\
\hline $\begin{array}{c}\text { GR }(\mathrm{mmol} \mathrm{min} \\
\left.\text { protein }^{-1}\right) \times 10^{5}\end{array}$ & $0.652 \pm 0.117 \mathrm{a}$ & $1.236 \pm 0.225 \mathrm{ab}$ & $2.669 \pm 0.477 \mathrm{~b}$ & $1.476 \pm 0.473 \mathrm{ab}$ & $1.237 \pm 0.281 \mathrm{ab}$ & $2.618 \pm 0.032 \mathrm{ab}$ & $1.337 \pm 0.205 \mathrm{ab}$ & $0.670 \pm 0.309 \mathrm{a}$ \\
\hline
\end{tabular}


fixation (Fig. 3) during cold acclimation. However, they recovered rapidly when returned to the normal condition of $25 / 20^{\circ} \mathrm{C}$. These results suggest that the effects of low temperature such as the reduction of RWC and $\mathrm{CO}_{2}$ fixation during cold acclimation in this experiment are short-term and temporary phenomena. Although $P$. glehnii is cold tolerant, this plant showed a decrease in RWC during cold acclimation. However, cold-acclimated needles held a higher level of water than non-acclimated needles in the subsequent chilling condition $\left(0^{\circ} \mathrm{C}\right.$, for 2 weeks) (Fig. 2C, D). The improved water retention ability of cold-acclimated needles may have an important effect on the protection of photosynthetic apparatus at low temperatures.

\section{PSII Efficiency and Chlorophyll Fluorescence}

The decrease in PSII efficiency (Fv/Fm) during cold acclimation may be related directly to damage to the PSII complex and interconversion of the xanthophyll-cycle pigments. So then, what parameters are most sensitive to cold, and what mechanism is responsible for cold tolerance in the photosynthetic apparatus of $P$. glehnii? To elucidate these questions, we measured the fluorescence parameters, Fo, Fv and Fm. Changes in chlorophyll fluorescence can indicate biotic and abiotic stresses on PSII (Kornyeyev et al. 2001). The decrease in PSII efficiency (Fig. 4A, B) and sudden decline in Fv (Fig. 6A, B) during cold acclimation were marked in 0 -YONs. Cold-acclimated 0-YONs and 1-YONs showed higher PSII efficiency than non-acclimated ones during subsequent chilling (Fig. 4C, D). Photoinhibition, such as decreased PSII efficiency (due to an increase in the Fo level and a decrease in the Fv level), is a kind of oxidative stresses that may be caused by an imbalance between supply and utilization of energy for photosynthesis at low temperatures. In this experiment, needles previously exposed to a sufficiently low temperature (for examples, 1-YONs that have experienced natural low temperatures in the previous winter and coldacclimated 0 -YONs in this experiment) showed less damage to the photosynthetic apparatus at low temperature, whereas needles that had no previous experience of low temperatures exhibited serious damage in the reaction center (decreases in $\mathrm{Fv}$ and $\mathrm{Fv} / \mathrm{Fm}$ ) when they were chilled (Fig. 6). This result suggests that cold acclimation played a major role in protection of the reaction center of PSII when plants were re-exposed to low temperatures, and also permitted faster recovery of the reaction center when the needles were returned to normal conditions.

\section{Xanthophyll-Cycle Pigments and De-Epoxidation Ratio}

The increase in lutein, $\beta$-carotein (in stage 1 in 0 -YONs) and zeaxanthin (in stage 2 of cold acclimation in 0-YONs and 1-YONs) indicated the development of energy dissipation mechanisms to protect the needles from photodamage. The photoprotective role of pigments of the xanthophyll-cycle has been studied intensively (Demmig-Adams and Adams 1992): zeaxanthin is an important antioxidant in the thylakoid membrane that diminishes excessive energy through thermal dissipation (Tardy and Havaux 1997). Recent research also showed a role of lutein in heat dissipation in PSII (Bassi and Caffarri 2000). In this experiment, high levels of zeaxanthin, de-epoxidation ratios and increased $\mathrm{qN}$ in the cold-acclimated needles suggest that non-photochemical quenching through the xanthophyll-cycle plays an important role in the protection and repair of PSII against photodamage in P. glehnii. Similarly, several studies have shown that de-epoxidation is immediately induced by photoinhibition, and that zeaxanthin is engaged in the repair process of PSII (Gray et al. 1997, Jahns et al. 2000, Jin et al. 2001). The interesting thing is that 1 -YONs eliminated excitation energy through both non-photochemical and photochemical quenching, while 0YONs depended almost entirely on non-photochemical quenching for dissipation of excessive energy during cold acclimation in $P$. glehnii.

\section{Ascorbate-Glutathione Cycle Enzymes}

Oxidative stress at low temperatures is induced by the reactive oxygen species (ROS) formed as a result of excess energy reacting on oxygen molecules (Aroca et al. 2001). Plants have evolved several mechanisms to prevent damage by ROS. Tolerance to an adverse environment is correlated with an increased capacity to scavenge or detoxify ROS (Malan et al. 1990). In addition, research on winterinjuries in coniferous needles has shown a correlation between increases in the activities of SOD and APX in winter and freezing tolerance (Jin et al. 1989, Tao et al. 1992). In this experiment, the increased antioxidant enzyme activity in 1-YONs (in stage 1 of cold acclimation) as soon as the needles were exposed to low temperatures suggests that enzymes of the ascorbate- glutathione cycle began scavenging ROS immediately to protect the photosynthetic apparatus of 1-YONs against inactivation by cold stress. In coldacclimated 1-YONs, after quickly increasing when exposed to low temperature, the activities of their enzymes then decreased and remained at lower levels. We think that the low activities of antioxidant enzymes in cold-acclimated 1-YONs reflect the avoidance of oxidative stress through a rapid increase in the activities of antioxidant enzymes as soon as the needles were exposed to low temperatures. Similarly, well-acclimated high mountain plants show low levels of non-enzymic antioxidants and antioxidant enzyme activity (Streb et al. 1998). In contrast to 1-YONs, 0-YONs showed increased enzyme activity during treatment with continuous low temperature (in stage 2 of cold acclimation) and maintained a high level of the activities throughout the treatment. These results su- 
ggest that the antioxidant defense mechanism of 1-YONs may protect the PSII from initial photo-oxidative damage of PSII by acting rapidly upon exposure to low temperature. In conclusion, when plants are re-exposed to low temperatures, antioxidant enzymes in cold-acclimated needles play an important protective role in preventing photo-oxidative damage by reacting quickly and continuously. In addition, cold-acclimated needles showed non-photochemical quenching of xanthophyll-cycle-dependent thermal energy dissipation at low temperature. The recent increase in the average temperature of the earth resulting from human activities may disturb the cold acclimation process of woody plants. Our results indicate that cold acclimation has a clear association with the development of physiological or biochemical factors facilitating cold tolerance in P. glehnii. Therefore, we predict that when the cold acclimation process is disturbed, woody plants will be a risk of suffering more serious damage as a result of low temperature shock.

\section{ABBREVIATIONS}

A: antheraxanthin

ABA: abscisic acid

APX: ascorbate peroxidase

AsA: ascorbate

GR: glutathione reductase

GSSG: glutathione disulphide

Fm: fluorescence when all PS II reaction centres are closed in dark-exposed leaves

Fo: fluorescence of leaves in the dark when all PS II reaction centres are open

Fv: variable fluorescence

Fv/Fm: maximum quantum yield of PS II

NADH: nicotinamide adenine denucleotide

NADPH: nicotinamide adenine denucleotide phosphate

$\mathrm{O}_{2}^{-}$: superoxide radical

PS: photosystem

qN: non-photochemical quenching of chlorophyll fluorescence

qP: photochemical quenching of chlorophyll fluorescence

ROS: reactive oxygen species

sAPX: stromal APX

tAPX: thylakoid-bound APX

$\mathrm{V}$ : violaxanthin

Z: zeaxanthin

\section{ACKNOWLEDGMENTS}

"This work was supported by the Korean Research Foundation Grant (KRF-2005-214-C00127), also CREST grant, ILTS grant.”

\section{LITERATURE CITED}

Aroca R, Irigoyen JJ, Sánchez-Díaz M. 2001. Photosynthetic characteristics and protective mechanisms against oxidative stress during chilling and subsequent recovery in two maize varieties differing in chilling sensitivity. Plant Sci 161: 719-726.

Bassi R, Caffarri S. 2000. LHC proteins and the regulation of photosynthetic light harvesting function by xanthophylls. Photosyn Res 64: 243-256.

Cameron RWF, Harrison-Murray RS, Scott MA. 1999. The use of controlled water stress to manipulate growth of container-grown Rhododendron cv. Hoppy. J Hort Sci Btiotech 74: 161-169.

Demmig-Adams B, Adams III WW. 1992. Photoprotection and other responses of plants to high light stress. Ann Rev Plant Physiol Plant Mol Biol 43: 599-626.

Gilmore AM, Yamamoto HY. 1991. Resolution of lutein and zeaxanthin using a nonendcapped, lightly carbon-loaded C-18 high performance liquid chromatographic column. J Chromatogr 543: 137145.

Gray GR, Chauvin LP, Sarhan F, Huner NPA. 1997. Cold acclimation and freezing tolerance. A complex interaction of light and temperature. Plant Physiol 114: 467-474.

Heide OM. 1993. Daylength and thermal time responses of bud-burst during dormancy release in some northern deciduous trees. Physiol Plant 88: 531-540.

Jahns P, Depka B, Trebst A. 2000. Xanthophyll cycle mutants from Chlamydomonas reinhardtii indicate a role for zeaxanthin in the D1 protein turnover. Plant Physiol Biochem 38: 373-376.

Jin ES, Polle JWE, Melis A. 2001. Involvement of zeaxanthin and of the Cbr protein in the repair in of photosystem-II from photoinhibition in the green alga Dunaliella salina. Biochim Biophys Acta 1506: 244-259.

Jin YH, Tao DL, Du YJ. 1989. Freezing tolerance, pigments and SOD of five conifers in Shenyang. Acta Bot Sin 32: 702-706.

Kacperska-Palacz A. 1978. Mechanism of cold adaptation in herbaceous plants. In: Li PH, Sakai A. (eds). Plant cold hardiness and freezing stress-mechanism and crop implications. Academic Press, New York. pp. 139-152.

Kornyeyev D, Logan BA, Payton P, Allen R, Holaday AS. 2001. Enhanced photochemical light utilization and decreased chillinginduced photoinhibition of photosystemII in cotton overexpressing genes encoding chloroplast-targeted antioxidant enzymes. Physiol Plant 113: 323-331.

Malan C, Greyling MM, Gressel J. 1990. Correlation between Cu/Zn superoxide dismutase and glutathione reductase, and environmental and xenobiotic stress tolerance in maize inbreeds. Palnt Sci 69: 157-166.

Murelli C, Rizza F, Albini FM, Dulio A, Terzi V, Cattivelli L. 1995. Metabolic changes associated with cold-acclimation on contrastion cultivars of barley. Physiol Plant 94: 87-93.

Öquist G, Huner NPA. 1991. Effects of cold acclimation on the sus- 
ceptibility of photosynthesis to photoinhibition in Scots pine and winter and spring cereals: a fluorescence analysis. Funct Ecol 5: 91-100.

Pearce RS. 1999. Molecular analysis of acclimation to cold. Plant Growth Regul 29: 47-76.

Strand A, Hurry V, Henkes S, Huner N, Gustafsson P, Gardeström P, Stitt M. 1999. Acclimation Arabidopsis thaliana leaves developing at low temperatures. Increasing cytoplasmic volume accompanies increased activities of enzymes in the Calvin cycle and in the sucrose-biosynthesis pathway. Plant Physiol 119: 1387-1397.

Streb P, Shang W, Feierabend J. 1998. Divergent strategies of photo- protection in high-mountain plants. Planta 207: 313-324.

Tao DL, Jin YH, Du YJ, Liu GZ, Zhan RY. 1992. Responses of organic free-radicals production of overwintering conifer needles to low temperature and light. Chin J Appl Ecol 3: 120-124.

Tardy F, Havaux M. 1997. Thylakoid membrane fluidity and thermostability during the operation of the xanthophylls cycle in higherplant chloroplasts. Biochim Biophys Acta 1330: 179-193.

Veisz O, Galiba G, Sutka J. 1996. Effect of abscisic acid on the cold hardiness of wheat seedlings. J Plant Physiol 149: 439-443.

(Received October 22, 2008; Accepted November 11, 2008) 